\title{
PENGARUH UKURAN PERUSAHAAN, KEBIJAKAN DIVIDEN, KEBIJAKAN LEVERAGE, KEPEMILIKAN MANAJERIAL DAN PROFITABILITAS TERHADAP NILAI PERUSAHAAN PADA INDEKS LQ45 YANG TERDAFTAR DI BURSA EFEK INDONESIA
}

\author{
Mursidah Nurfadillah \\ Mn874@umkt.ac.id \\ Vera Anitra \\ Va674@umkt.ac.id \\ Universitas Muhammadiyah Kalimantan Timur
}

\begin{abstract}
This study aims to analyze the effect of company size, dividend policy, leverage policy, managerial ownership and profitability on firm value on the $L Q 45$ index listed on the Indonesia stock exchange. The technique of collecting time series data for five years is from 2013 to 2017, by analyzing the LQ 45 company's annual report. This type of research is included in causal research with quantitative methods, and data analysis techniques using multiple linear regression. The results of the analysis show that simultaneous company size, dividend policy, leverage policy, managerial ownership and profitability have a significant effet on firm value, whereas only partially only company size have a significant effect.
\end{abstract}

Keyword: ukuran perusahaan, kebijakan dividen, kebijakan leverage, kepemilikan manajerial, profitabilitas, nilai perusahaan

\section{PENDAHULUAN}

Setiap perusahaan memiliki tujuan untuk mencapai keuntungan, selain itu bertujuan untuk mensejahterakan pemilik perusahaan dan para pemegang saham (shareholder). Dan tujuan perusahaan yang merupakan tujuan jangka panjang yang seharusya dicapai perusahaan adalah memaksimalkan nilai perusahaan. Dengan meningkatnya nilai sebuah perusahaan maka kesejahteraan pemilik perusahaan dan para pemilik saham juga akan meningkat, sehingga kepercayaan investor untuk menanamkan modalnya di perusahaan tersebut juga semakintinggi.

Para investor atau pemegang saham akan melihat bagaimana nilai perusahaan tersebut sebelum melakukan investasi, hal ini dikarenakan nilai perusahaan dapat menunjukkan kemakmuran para pemegang saham. Nilai perusahaan merupakan suatu ukuran yang telah dicapai oleh perusahaan sebagai gambaran dari kepercayaan masyarakat terhadap perusahaan tersebut setelah melalui suatu proses kegiatan operasional selama beberapa tahun, mulai dari sejak perusahaan tersebut didirikan sampai dengan beroperasi saat ini (Septia dan Lina, 2015). Dengan tingginya nilai perusahaan maka perusahaan akan dipandang baik oleh para calon investor.

Nilai perusahaan merupakan pandangan investor terhadap tingkat keberhasilan perusahaan, dalam mengelola sumber daya pada akhir tahun berjalan yang terlihat pada harga saham perusahaan. Semakin tinggi harga saham maka semakin tinggi pula nilai perusahaan, begitupula sebaliknya semakin rendah harga saham maka akan rendah pula nilai perusahaan,yang artinya kinerja perusahaan kurang baik. Para investor tentunya sangat selektif dalam memilih perusahaan untuk menanamkan modalnya, karena nilai perusahaan merupakan faktor yang dipertimbangkan oleh para investor untuk menanamkan modalnya. Nilai Perusahaan merupakan suatu gambaran dari kepercayaan masyarakat terhadap perusahaan yang telah melalui suatu proses kegiatan selama beberapa tahun, yaitu sejak perusahaan tersebut berdiri hingga saat ini (Noerirawan, 2012). Semua perusahaan yang terdaftar di BEI tentunya menginginkan saham di perusahaan mereka memiliki potensi harga tinggi serta dapat menarik minat investor untuk membeli saham di perusahaan tersebut (Dwi,2013).

Ada beberapa faktor yang dipertimbangkan investor dalam berinvestasi dan dapat 
mempengaruhi nilai perusahaan, diantaranya ukuran perusahaan, kebijakan dividen, kebijakan leverage, kepemilikan manjerial dan profitabilitas. Berdasarkan hal tersebut maka penelitian ini akan menganalisis bagaimana pengaruh faktor - faktor tersebut bagi nilai perusahaan.

\section{TINJAUAN TEORITIS}

Nilai perusahaan dapat menggambarkan seberapa besar manfaat yang akan diperoleh investor dari suatu perusahaan. Nilai perusahaan adalah suatu ukuran yang dicapai oleh perusahaan sebagai bentuk gambaran dari kepercayaan masyarakat terhadap perusahaan tersebut setelah melalui proses kegiatan operasional selama beberapa tahun, dimulai sejak perusahaan tersebut didirikan sampai dengan beroperasi saat ini(Ade Winda Septia dan Lina,2015).Artinya jika banyak investor yang berinvestasi maka harga saham akan meningkat dan jika harga saham meningkat, nilai perusahaan juga akan meningkat karena pada dasarnya nilai perusahaan diukur dari beberapa aspek. Salah satu aspeknya adalah harga pasar saham perusahaan, harga pasar saham perusahaan mencerminkan penilaian investor atas keseluruhan ekuitas yang dimiliki suatu perusahaan ( Fernandar dan Raharja,2012).

Semakin tinggi harga saham, maka nilai perusahaan pun akan ikut tinggi. Meningkatnya nilai perusahaan adalah salah satu tujuan, yang sesuai dengan keinginan para pemiliknya, Artinya semakin tinggi nilai perusahaan, maka kesejahteraan shareholdernya semakin baik (Fernandar dan Raharja, 2012).Jadi, bisa dikatakan nilai perusahaan adalah sebuah nilai yang menunjukkan keadaan umum suatu perusahaan.Para investor menjadikan nilai perusahaan suatu patokan untuk menilai apakah perusahaan tersebut dapat memberikan keuntungan atau perusahaan tersebut memiliki prospek yang baikkedepannya.

Menurut Brigham dan Houston (2011) nilai perusahaan dipengaruhi oleh beberapa faktor,yaitu:

1) RasioLikuiditas.

2) Rasio ManajemenAset

3) Rasio Manajemen Hutang(leverage)

4) RasioProfitabilitas

Menurut Indriyo Gitosudarmo dan Basri (2014) faktor-faktor yang menjadi pedoman perusahaan untuk memaksimalkan nilai perusahaan adalah:
1. RisikoPerusahaan.

2. Dividen.

3. PertumbuhanPerusahaan.

4. HargaSaham.

Dalam penelitian ini variabel nilai perusahaan diwakili oleh price to book value (PBV), karena price to book value banyak digunakan dalam pengambilan keputusan investasi, price to book value juga mencerminkan seberapa tinggi pasar menghargai nilai buku saham suatu perusahaan. (Desy Septariani, 2017).

Nilai perusahaan antara lain dipengaruhi oleh ukuran perusahaan dan kebijakan dividen. Perusahaan dengan ukuran yang besar, akan memiliki penyesuaian dan kemudahan dalam upayanya untuk mendapatkan dana dari pasar modal. Dari kemudahan tersebut, selanjutnya akanditangkap oleh investor sebagai sinyal positif serta harapan yang baik dari suatu perusahaan. Dimana hal tesebut menjadikan pengaruh positif terhadap nilai perusahaan (Hardiyanti, 2012).Ukuran perusahaan dapat dilihat dari total aktiva suatu perusahaan, aktiva merupakan suatu cerminan dari pendapatan dan aset yang dimiliki oleh perusahaan, semakin besar aktiva maka semakin tinggi nilai perusahaan. Selain itu, ukuran perusahaan menjadi pertimbangan untuk mendapatkan modal di pasar modal, ukuran perusahaan yang besar dapat lebih mudah aksesnya terhadap pasar modal dalam memperoleh pendanaan bagiperusahaannya.

Nilai perusahaan juga dapat dilihat dari kemampuan perusahaan dalam membayarkan dividen, namun keputusan itu kembali lagi pada kebijakan dari perusahaan apakah dividen akan dibayarkan ataukah tidak. Ketika membuat suatu kebijakan dividen, satu ukuran saja tidak akan dapat digunakan oleh semua orang, karena banyaknya perbedaan prinsip pada setiap pemegang saham. Harga saham dapat dipengaruhi dari besarnya dividen.Harga saham cenderung naik ketika dividen yang dibayarkan tinggi, keadaan itu dapat berpengaruh sehingga nilai perusahaan juga tinggi, begitu pula sebaliknya(Mardiyanthi, 2012).Kemampuan perusahaan memperoleh laba berhubungan erat dengan kemampuan perusahaan membayar dividen. Ketika perusahaan mampu membayar dividen yang besar, artinya perusahaan akan memperoleh laba yang besar juga (Prasetyo, 2013). Oleh karena itu, peningkatan nilai perusahaan juga dipengaruhi dengan tingkat dividen yang tinggi (Martono dan Harjito,2010).

Faktor lain yang mempengaruhi nilai perusahaan serta menjadi perhatiaan oleh para 
investor sebelum menanamkan modalnya adalah kebijakan hutang suatu perusahaan. Menurut Weston dan Copeland dalam Titin Herawati (2013), kebijakan penggunaan hutang dalam perusahaan juga dapat mempengaruhi nilai perusahaan.hal ini berkaitan dengan biaya yang akan dikeluarkan akibat penggunaan hutang serta manfaat yang didapatkan dari penggunaan hutang. Kebijakan hutang perlu dikelola dengan baik karena penggunaan hutang yang tinggi akan meningkatkan nilai perusahaan. Artinya semakin tinggi proporsi hutang yang ditetapkan oleh perusahaan pada tingkat yang telah ditentukan, maka semakin tinggi nilai perusahaan (Mardiyati, 2012). Tapi jika tingkat hutang melebihi proporsi yang ditetapkan oleh perusahaan, maka nilai perusahaan akan turun karena manfaat yang diperoleh dari penggunaan hutang relatif kecil daripada biaya yang ditimbulkannya (Septariani, 2017).

Selain kebijakan hutang yang menjadi faktor yang mempengaruhi nilai perusahaan, kebijakan dividen juga menjadi salah satu faktor yang berpengaruh terhadap nilai perusahaan.Kemampuan membayar dividen saling berkaitan dengan kemampuan perusahaan memperoleh laba/keuntungan.Jika perusahaan memperoleh laba/keuntungan yang besar, maka kemampuan perusahaan dalam membayar dividen juga besar. Apabila dividen yang dibayar tinggi kepada para pemegang saham, maka harga saham akan cenderung tinggi sehingga nilai perusahaan juga ikut tinggi. Sebaliknya jika dividen yang dibayarkan kecil maka harga saham perusahaan tersebut juga rendah. Oleh karena itu, dengan dividen yang besar akan meningkatkan nilai perusahaan (Matono dan Agus Harjito, 2005). Artinya semakin besar dividen yang dibagikan, maka hal tersebut dapat mengundang para investor untuk menanamkan modalnya dan akan membuat harga saham semakin tinggi. Jika hal tersebut terjadi maka nilai suatu perusahaan pun akan semakin tinggi.

Faktor yang juga mempengaruhi nilai perusahaan adalah kepemilikan manajerial.Kepemilikan manajerial diukur dari jumlah prosentase saham yang dimiliki manajer.Adapun menurut Faisal (2003), alat ukur yang digunakan untuk variabel kepemilikan manajerial adalah persentase saham direktur dan komisaris.Dari pengertian diatas dapat disimpulkan kepemilikan manajerial merupakan presentase saham yang dimiliki manajer dan direksi suatu perusahaan.Dalam laporan keuangan yang dipublikasikan oleh emiten kepemilikan saham dilaporkan dalam bentuk persentase, kepemilikan manajerial ini merupakan kompensasi yang diberikan perusahaan kepada karyawannya.

Kepemilikan manajerial dapat mempengaruhi pencapaian tujuan perusahaan dan nilai perusahaan. Perusahaan harus memperhatikan kepemilikan manajerial yang ada dalam perusahaan karena dapat berpengaruh terhadap keputusan keuangan perusahaan yang pada akhirnya akan mempengaruhi nilai perusahaan.

Nilai perusahaan juga dapat dipengaruhi oleh faktor lain yang berasal dari internal perusahaan salah satunya adalah profitabilitas. Profitabilitas merupakan salah satu faktor yang secara teoritis menentukan nilai suatu perusahaan. Perusahaan yang mampu menghasilkan laba besar dan stabil akan menarik para investor, karena secara otomatis akan menguntungkan investor. Dengan menumbuhkan kepercayaan pada investor ini dapat menjadi instrumen yang baik dan efektif untuk mengangkat harga saham, yang pada akhirnya akan berdampak pada peningkatan nilai perusahaan.

\section{Kerangka Konsep}

Gambar 1

Kerangka Konsep

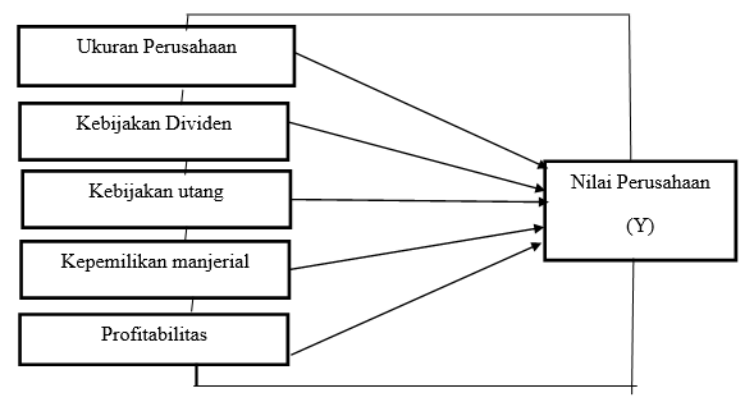

\section{Hipotesis}

H1 : Ukuran perusahaan, kebijakan dividen, kebijakan leverage, kepemilikan manjerial dan profitabilitas secara simultan berpengaruh terhadap nilai perusahaan pada Indeks LQ45 yang terdapat di Bursa EfekIndonesia

H2 : Ukuran perusahaan, kebijakan dividen, kebijakan leverage, kepemilikan manjerial dan profitabilitas secara parsial berpengaruh terhadap nilai perusahaan pada Indeks LQ45 yang terdapat di Bursa EfekIndonesia

\section{METODE PENELITIAN}

Jenis penelitian termasuk dalam penelitian kausaldenganmetode kuantitatif.Penelitian dilakukan terhadap perusahaan LQ45 yang terdaftar di Bursa Efek Indonesia dengan menganalisis laporan 
keuangan perusahaan selama periode tahun 2013 sampai dengan 2017.Sampel penelitian ditentukan dengan menggunakan metode purposive samplingsehingga diperoleh jumlahsampel penelitian sebanyak 10 perusahaan.Adapun variabel yang digunakan dalam penelitian ini teridri dari:

1. Variabel dependen(Y)

Variabel dependen yang digunakan dalam penelitian ini adalah nilai perusahaan. Dalam penelitian ini variabel nilai perusahaan diwakili oleh price to book value (PBV), yang dirumuskan sebagai berikut :

Price to Book Value $=\frac{\text { Harga Perlembar Saham }}{\text { Nilai Buku Perlembar }}$

2. Variabel Independen $(\mathrm{X})$

a. Ukuran Perusahaan(X1)

Dalam Penelitian ini ukuran perusahaan dinilai dengan $\log$ of total assets.Log Of Total Assets ini digunakan untuk mengurangi perbedaan signifikan antara ukuran perusahaan yang

terlalubesardenganukuranperusahaanyangterlal ukecil,makanilaitotalassetdibentuk menjadi logaritma natural, konversi kebentuk logaritma natural ini bertujuan untuk membuat data total asset terdistribusi normal.

$\mathrm{SIZE}=\mathrm{Ln}$ total assets

b. Kebijakan Dividen(X2)

Dividend Payout Ratio (DPR) dipakai sebagai alat ukur kebijakan dividen, dihitung dengan:

$$
\text { Dividend Payout Ratio }=\frac{\text { Dividend Tunai Persaham }}{\text { Laba Persaham }}
$$

c. Kebijakan Hutang(X2)

Debt to equity ratio digunakan untuk menunjukkan kemampuan perusahaan membayar semua kewajiban jangka panjang dan jangka pendek, dengan rumus :

$$
\text { Debt to equity ratio }=\frac{\text { Total Hutang }}{\text { Equitas }} \times 100 \%
$$

d. Kepemilikanmajerial

Jumlah modal yang dimiliki oleh pihak manajerial, yang dinyatakan dalam persentase.

e. Profitabilitas(X2)

Return On Assets (ROA) merupakan rasio profitabilitas yang digunakan untuk mengukur efektifitas perusahaan di dalam menghasilkan keuntungan dengan memanfaatkan aktiva yang dimilikinya, yang diformulasikan sebagaiberikut:

$$
\text { ROA }=\frac{\text { Laba Bersih }}{\text { TotalAset }} \times 100
$$

Berdasarkan kerangka konsep yang telah dijelaskan maka teknik analisis data yang digunakan adalah regresi linear berganda dengan menggunakan program SPSS versi 23 (Statistical Package for the Social Science) dengan tingkat kepercayaan 95\% ( $\alpha$ $=5 \%$ ) dan pengujian hipotesis dengan menggunakan uji $F$ dan uji t.

\section{ANALISIS DAN PEMBAHASAN}

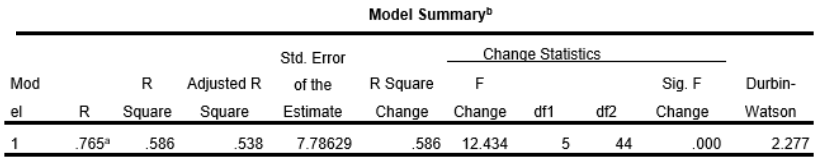

Pengujian hipotesis dalam penelitian ini dilakukan melalui alat analisis regresi linear berganda. Tabel berikut ini menunjukkan hasil analisis regresi dengan tingkat singnifikansebesar $5 \%(\alpha=5 \%)$.

Angka R dari tabel 1 adalah sebesar 0,765, hal ini menunjukkan bahwa hubungan atau korelasi antara return saham dengan variabel independennya adalah kuat, karena berkisar diantara 0,60 - 0,799 (Sugiyono, 2011 : 231) dan pengaruh variabel independen terhadap variabel dependenditunjukkan oleh nilai Adjusted $\mathrm{R}^{2}$ sebesar 0,538. Hal ini menggambarkan bahwa pengaruh ukuran perusahan, kebijakan dividen, kebijakan hutang, kepemilikan perusahaan dan profitabilitas terhadap nilai perusahaan sebesar 58,3\% dan sisanya 41,7\%(100\%

- 58,3\%) dipengaruhi oleh variabel lain diluar penelitian.

Besarnya Nilai Fhitung lebih besar dari Ftabel(12, 434>2,427) dan tingkat Signifikansi F $<5 \%(0.000<0.05)$. Hal ini menunjukkan bahwa terdapat pengaruh yang signifikan secara simultan antaraukuran perusahan, kebijakan dividen,

\begin{tabular}{|c|c|c|c|c|c|c|}
\hline \multirow[b]{2}{*}{ Model } & & \multicolumn{2}{|c|}{ Unstandardized Coefficients } & \multirow{2}{*}{$\begin{array}{c}\text { Standardized } \\
\text { Coefficients } \\
\text { Beta }\end{array}$} & \multirow[b]{2}{*}{ t } & \multirow[b]{2}{*}{ Sig. } \\
\hline & & $\mathrm{B}$ & Std. Error & & & \\
\hline \multirow[t]{6}{*}{1} & (Constant) & 55.948 & 25.405 & & 2.202 & .033 \\
\hline & LN_ASSET & -3.118 & 1.319 & -.278 & -2.364 & .023 \\
\hline & DPR & .103 & .056 & .205 & 1.836 & .073 \\
\hline & DER & 4.359 & 2.300 & .241 & 1.895 & .065 \\
\hline & кM & 17.125 & 10.035 & .214 & 1.707 & .095 \\
\hline & ROA & .168 & .140 & . 180 & 1.198 & .237 \\
\hline
\end{tabular}
kebijakan hutang, kepemilikan perusahaan dan profitabilitas terhadap nilai perusahaan

a. Dependent Variable: PER

Berdasarkan tabel tersebut, maka persamaan regresi linear berganda secara sistematis sebagai berikut : 
$\mathrm{Y}=55,948-0,168 \mathrm{X} 1+4,359 \quad \mathrm{X} 2+0,103 \mathrm{X} 3+$ $17,125 \mathrm{X} 4-3,188 \mathrm{X} 5+\mu \mathrm{i}$

Hasil pengujian secara parsial (Uji-t) menunjukkan ukuran perusahan, kebijakan dividen, kebijakan hutang, kepemilikan perusahaan tidak berpengaruh signifikan terhadap nilai perusahaan dan hanya profitabilitas yang berpengaruh signifikan terhadap nilai perusahaan.Secara parsial pengaruh masing - masing variabel indenpenden dapat diuraikan sebagai berikut :

1. Ukuranperusahaan

Secara parsialukuran perusahaan yang diproksikan oleh nilai total asset berpengaruh signifikan terhadap nilai perusahaan dengan nilai signifikansi sebesar 0,023. Nilai koefisien regresi ukuran perusahaansebesar - 3,118, menunjukkan hubungan yang berlawananan arah terhadap nilai perusahaan, , artinya pada saat ukuran perusahaan naik sebesar $1 \%$ maka nilai perusahaan akan turun sebesar- $3,118 \%$ dan sebaliknya pada saat ukuran perusahaan turun $1 \%$ maka nilai perusahaan akan naik sebesar3,118\%.

2. Kebijakandividen

Secara parsial kebijakan dividen yang diwakili oleh dividend payout ratio(DPR) tidak berpengaruh signifikan terhadap nilai perusahaan LQ 45.Nilai koefisien regresi DPRsebesar 0,103 yang menunjukkan hubungan searah terhadap nilai perusahaan. Hal ini berarti bahwa pada saat kebijakan dividennaik sebesar $1 \%$ maka nilai perusahaanjuga akan naik sebesar $0,103 \%$ dan sebaliknya pada saat kebijakan dividen turun $1 \%$ maka nilai perusahaan juga akan mengalami penurunan sebesar $0,103 \%$.

3. KebijakanHutang

Secara parsialkebijakan hutang yang diproksikan oleh debt to equity ratio(DER) tidak berpengaruh signifikan terhadap nilai perusahaanperusahaan LQ 45.Nilai koefisien regresi DER pada sebesar 4,359, yang menunjukkan hubungan searah dengan nilai perusahaan.
Hal ini berarti bahwa pada saat kebijakan hutang naik sebesar $1 \%$ maka nilai perusahaan juga akan naik sebesar 4,359\% dan sebaliknya pada saat kebijakn hutang turun sebesar $1 \%$ makan nilai perusahaanjuga akan turun sebesar 4,359\%.

4. Kepemilikanmanajerial

Secara parsial kepemilikan manajerialpada perusahaan LQ 45 tidak mempunyai pengaruh signifikan terhadap nilai perusahaan.Nilai koefisien regresi kepemilkan manajerialsebesar 17,125 yang berarti menunjukkan hubungan searah terhadap nilai perusahaan. Hal ini berarti bahwa pada saatkepemilikan manajerial naik sebesar $1 \%$ maka nilai perusahaanLQ 45 akan naik sebesar $17,125 \%$, sebaliknya pada saat kepemilkan manajerial turun sebesar $1 \%$ maka nilai perusahaanjuga akan turun sebesar 17,125\%.

5. Profitabilitas

Secara parsial profitabilitas yang dinilai dari return on assets (ROA) pada perusahaan LQ 45 tidak mempunyai pengaruh signifikan terhadap nilai perusahaan. Nilai koefisien regresi kepemilkan manajerialsebesar 0,168 yang berarti menunjukkan hubungan searah terhadap nilai perusahaan. Hal ini berarti bahwa pada saat profitabilitas naik sebesar $1 \%$ maka nilai perusahaanLQ 45 akan naik sebesar $0,168 \%$, sebaliknya pada saat profitabilitasl turun sebesar $1 \%$ maka nilai perusahaanjuga akan turun sebesar $0,168 \%$.

Hasil penelitian menunjukkan secara simultan ukuran perusahaan, kebijakan dividen, kebijak hutang, kepemilikan manajerial dan profitabilitas berpengaruh signifikan terhadap nilai perusahaan, sedangkan secara parsial hanya ukuran perusahaan yang berpengaruh signifikan.

Berdasarkan hasil penelitian ini menunjukkan bahwa ukuran perusahaan berpengaruh negatif dan signifikan terhadap nilai perusahaan. Hal ini menandakan bahwa ukuran perusahaan 
merupakan rasio yang menjadi pertimbangan investor dalam menilai perusahaan sehingga akan mempengaruhi nilai perusahaan .Tetapi pada penelitian ini ukuran perusahaan mempunyai hubungan negative dengan nilai perusahaan.Hal ini dapat disebabkan banyaknya asset perusahaan yang tidak digunakan secara maksimal sehingga hal tersebut dapat merugikan perusahaan dikarenakan asset tersebut tidak memberikan output yang maksimal. Penelitian ini tidak sejalan dengan dasar teori yang menyatakan bahwa ukuran perusahaan berpengaruh positif dan signifikan terhadap nilai perusahaan, kemungkinan hal ini bisa terjadi karena kenaikan data pada ukuran perusahaan tidak seiring dengan kenaikan data pada nilai perusahaan, sehingga menghasilkan angka negatif..Penelitian ini sesuai dengan hasil penelitian yang dilakukan oleh Nurmala (2016).Hasil penelitian tersebut menyatakan bahwa secara parsial Size perusahaan berpengaruh signifikan terhadap price earning ratio(PER).

Kebijakan dividen terkait dengan masalah penggunaan laba yang menjadi hak para pemegang saham.Laba tersebut dapat dibagi sebagai dividen atau ditahan untuk diinvestasikan kembali. Banyak investor yang mengharapkan dividen dan kenaikan harga saham dari perusahaan yang dipilih, sehingga apabila perusahaan membagikan dividen secara baik dan wajar, maka perusahaan akan mendapatkan timbal balik yang positif dari investor, dan hal ini dapat membantu dalam memelihara nilai perusahaan agar semakin baik.Penelitian ini sesuai dengan hasil penelitian yang dilakukan oleh Fanny Rifqi dan Rudi (2012) yang menyatakan bahwa dividend payout ratio (DPR) berpengaruh postitif dan signifikan terhadap price earning ratio (PER).Dan penelitian yang dilakukan oleh Danta Sitepu dan Linda (2013).Hasil penelitiannya mengatakan bahwa Dividend payout ratio mempunyai pengaruh positif dan signifkan terhadap price earning ratio.

Jika melihat pada kebijakan utang yang ditunjunjukkan oleh debt to equity ratiodapat disimpulkan bahwa DER tidak berpengaruh signifikan terhadap nilai perusahaan, artinya besar kecilnya hutang perusahaan LQ 45 tidak berpengaruh signifikan terhadap nilai perusahaannya.Hal ini didukung dengan penelitian terdahulu oleh Wenny Rizky Dewanti (2016) yang membuktikan bahwa tingginya hutang tidak berpengaruh signifikan terhadap nilai perusahaan.Tidak berpengaruhnya kebijakan hutang terhadap nilai perusahaan menunjkkan kepercayaan yang tinggi dari investor terhadap keamanan finansiil dari perusahaan LQ 45.Artinya meskipun utang mengalami peningkatan tetapi dengan modal dan manajemen yang baik dari perusahaan maka perusahaan malah dapat mengoptimalkan hutang untuk peningkatan nilaiperusahaan.

Berdasarkan hasil analisis dapat terlihat bahwa kepemilikan manajerial tidak pengaruh signifikan terhadap nilai perusahaan.Hal ini bertentangan dengan teori yang menyatakan bahwa Kepemilikan Manajerial merupakan salah satu faktor yang mempengaruhi nilai perusahaan. Kepemilikan manajerial ini diukur dengan berapa banyak pihak Manajerial perusahaan yang memiliki saham di perusahaan mereka dan hal itu akan mempengaruhi kinerja mereka dalam meningkatkan nilai perusahaan dan meningkatkan perusahaannya.

Tidak berpengaruhnya

kepemilikan manajerial terhadap nilai perusahaan dinyatakan oleh Benson dan Davinson (2008) bahwa kepemilikan manajerial berpengaruh negatif terhadap nilai perusahaan dengan penjelasan bahwa bila kepemilikan manajerial besar maka akan ada kecenderungan tindakan manajer yang oportunis dari manajer yangakanmenguntungkan diri sendiri. Hal ini terjadi karena manajer mencoba melakukan transfer kekayaan perusahaan kepada diri sendiri dengan mengambil kebijakan yang membesarkan aktiva dan laba. Tujuannya adalah untuk memperoleh bonus atau agar kinerjanya terlihat meningkat. Hal tersebut akan berdampak pada penurunan kinerja pasar yang pada akhirnya akan menurunkan nilai perusahaan.

Profitabillitas juga menunjukkan pengaruh yang tidak signifikan terhadap nilai perusahaan. Hal ini menunjukkan bahwa profitabilitas bukanlah menjadi ukuran utama bagi investor dalam berinvestasi di perusahaan LQ 45, Hasil penelitian ini selaras dengan penelitian 
yang dilakukan oleh Apriadi (2016) yang menyatakan bahwa profitabilitas tidak berpengaruh signifikan terhadap nilaiperusahaan.

\section{SIMPULAN DAN SARAN}

Berdasarkan analisis statistik menunjukkan bahwa secara simultan ukuran perusahaan, kebijakan dividen, kebijak hutang, kepemilikan manajerial dan profitabilitas berpengaruh signifikan terhadap nilai perusahaan dan secara parsial hanya ukuran perusahaan yang berpengaruh signifikan. Adapun saran dari penelitian ini agar perusahaan dapat bijak dalam mengambil keputusan dengan memperhatikan selalu aset yang dimiliki dengan hutang yang dimiliki agar seimbang sekiranya tidak melebihi batas yang telah ditentukan agar nilai saham pada perusahaan stabil tidak mengalami penurunan. Selain itu bagi perusahaan agar selalu memperhatikan nilai perusahaan yang dicapai karena menujukkan kepercayaan investor terhadap perusahaan yang bersangkutan, yaitu dengan cara melakukan inovasi agar perusahaan berkembang sehingga nilai perusahaan pada perusahaan tersebut semakin tinggi.

\section{DAFTAR PUSTAKA}

Aa Ngurah Dharma Adi Putra dan Putu Vivi Lestari, "Pengaruh Kebijakan Dividen, Likuiditas, Profitabilitas, dan Ukuran Perusahaan Terhadap Nilai Perusahaan." E-Jurnal Manajemen Unud, Vol. 5, No. 7, 2016: 40444070 .

Andinata, W. (2010).“Analisis Pengaruh Profitabilitas dan Kebijakan Dividen Terhadap Nilai Perusahaan Manufaktur di Bursa Efek Indonesia".Journal of Accounting Diponegoro University.

Aryati A, Sudirman, H. Rahman Mus, dan M. Tamrin. (2017). "Effect of profitability and dividend policy on corporate governance and firm value: Evidence from the IndonesianManufacturing Sectors". Journal of Business and Management, University of Muslim Indonesia.

Ayu Sri Mahatma D dan Ary W. (2013). "Pengaruh Struktur Modal, Profitabilitas dan Ukuran Perusahaan Pada Nilai Perusahaan". E-Jurnal Akuntansi Universitas Udayana Vol.4 No.2
Ayuningtyas.
Dwi.
(2013).“Pengaruh

Profitabilitas Terhadap Nilai

Perusahaan: Kebijakan Dividen dan Kesempatan Investasi Sebagai Variabel Antara". Jurnal STIESIA Surabaya.

Apriada, Kadek \& Suardikha, M. S. 2016. "Pengaruh Struktur Kepemilikan Saham, Struktur Modal dan Profitabilitas Pada Nilai Perusahaan" EJurnal Ekonomi dan Bisnis Universitas Udayana,Vol. 5, No. 2, hlm: 201-218

Benson, Bradly.W and Wallace N. Davinson. 2008. "Reexamining the Managerial Ownership Effect on Firm Value." Available on line at www.ssrn.com,

Brigham, Eugene F. dan Houston, Joel F. (2011)."Dasar-dasar Manajemen Keuangan Terjemahan”.Edisi 10. Jakarta: Salemba Empat.

Dompak P, dan Doli Natama L. T. (2018). "Analisis Pengaruh Sruktur Modal, Profitabilitas, Kebijakan Dividen dan Ukuran Perusahaan Terhadap Nilai Perusahaan Pada Perusahaan Farmasi Yang Terdaftar di Bursa Efek Indonesia (BEI)". Jurnal Akuntansi dan Keuangan Universitas Methodist Indonesia Vol.1 No.2.

Eka Lestari, Putu. (2010). "Pengaruh Struktur Modal dan Kepemilikan Manajerial Serta Ukuran Perusahaan terhadap Nilai Perusahaan pada Perusahaan Manufaktur di Bursa Efek Indonesia”. Skripsi Fakultas Ekonomi Universitas Udayana.

Fuad, Fanny Rifqi El \& Rudi Kurniawan. (2012). Pengaruh DPR, GRE, Dan Systematic Risk Terhadap Per: Uji Konsistensi Model. JEJAK Journal of Economics and Policy, 5 (2): 127- 229 doi: 10.15294jejak.v7i1.3596.

Ghozali, Imam. (2012). "Aplikasi Analisis Multivariate dengan Program IBM SPSS". Yogyakarta: Universitas Diponegoro.

Hardiyanti, Nia. (2012). "Analisis pengaruh Insider Ownership, Leverage, Profitabilitas, Firm Size dan Dividen Payout Ratio terhadap Nilai Perusahaan".Skripsi. UNDIP

Hermuningsih, Sri. (2012). "Pengantar Pasar Modal Indonesia”. Yogyakarta: UPP STIM YKPN. 
Jusriani, Ika. (2013). “Analisis Pengaruh Profitabilitas, Kebijakan Dividen, Kebijakan Utang, dan Kepemilikan Manajerial terhadap Nilai Perusahaan".Journal of Accounting DiponegoroUniversity.

Linda, Danta. S. (2013).“Analisis FaktorFaktor yang Mempengaruhi Price Earning Ratio pada Perusahaan Manufaktur di Bursa Efek Indonesia.Jurnal Wira Ekonomi Mikroskil Vol. 3 No. 02.

Mardiyanthi, Ika Fanindya. 2012.“Analisis Pengaruh Profitabilitas, Kebijakan Dividen, Kebijakan Utang, Dan Kepemilikan manajerial Terhadap Nilai Perusahaan (Studi Empiris pada Perusahaan Manufaktur yang Terdaftar di Bursa Efek Indonesia Periode 20092011)". Skripsi Fakultas Ekonomika Dan Bisnis Universitas Diponegoro Semarang.

Martalena dan Maya Malinda, (2011).'Pengantar Pasar Modal". Edisi Kesatu. Yogyakarta: ANDI.

Martono dan Agus Harjito, (2010). "Manajemen Keuangan (Edisi 3)". Yogyakarta:Ekonisia.

Maryam, Siti. (2014). “Analisis pengaruh firm size, growth, leverage, dan profitabilitas terhadap nilai perusahaan (studi pada perusahaan manufaktur yang terdaftar di bursa efek Indonesia)". Fakultas ekonomi dan bisnis Universitas Hasanudin: Makassar.

Noerirawan, Ronni, dkk. (2012). "Pengaruh Faktor Internal dan Eksternal Perusahaan Terhadap Nilai Perusahaan".Jurnal Akuntansi Vol.1 No. 2.Hal. 4.

Nor Hadi. (2013). "Pasar Modal: Acuan Teoretis Dan Praktis Investasi Di Instrument Keuangan Pasar Modal". Yogyakarta: Graha Ilmu.

Nurmala.(2016). “Analisis Faktor-Faktor yang Mempengaruhi Price Earning Ratio Perusahaan Manufaktur Sektor Industri Dasar dan Kimia di Bursa Efek Indonesia".Skripsi.Prigram Magister Universitas Terbuka Jakarta.
Nur Ahmadi Bi Rahmani, 2018. Pengaruh Return On Aset dan Return on Equity

Terhadap Price Earning Ratio, pada perusahaan yang terdaftar di JII. UniversitasIslam, Sumatera Utara.

Prasetyo, Eko. (2013). "Data Mining Konsep Dan Aplikasi Menggunakan Matlab". Yogjakarta: Penerbit Andi.

Rizqia, Dwita Ayu, Siti Aisjah dan Sumiati. (2013). "Effect of Managerial Ownership, Financial Leverage, Profitability, Firm Size, and Investment Opportunity on Dividend Policy and Firm Value". Research Journal of Finance and Accounting, Vol. 4, No.11 ISSN: 222201697. Postgraduate Program, Faculty of Economics and Business, Brawijaya University: Malang.

Rudangga I Gusti Ngurah Gede dan Gede Merta Sudiarta, 2016. "Pengaruh Ukuran Perusahaan, Leverage, dan Profitabilitas Terhadap Nilai Perusahaan". E- Jurnal Manajemen Unud, Volume 5, No. 07.

Sudana, I Made. (2011). "Manajemen Keuangan Perusahaan Teori dan Praktik”. Jakarta: Erlangga.

Sugiarto, Melanie. 2011. "Pengaruh Struktur Kepemilikan dan Kebijakan Dividen terhadap Nilai Perusahaan Dengan Kebijakan.Hutang Sebagai Intervening". Jurnal Akuntansi Kontemporer. 3 (1) h: 1-25

Sugiyono. (2015)."Metode Penelitian Pendidikan (Pendekatan Kuantitatif, Kualitatif, dan R\&D)". Bandung: Alfabeta.

Sukirni, Dwi. 2012. “Kepemilikan Manajerial, Kepemilikan Institusional, Kebijakan Dividen dan Kebijakan Hutang Analisis terhadap Nilai Perusahaan". Accounting Analysis Journal.Universitas Negeri Semarang.

Sunariyah, (2011). “Pengantar Pengetahuan Pasar Modal”. Edisi Keenam. Yogyakarta: UPP STIMYKPN. 
Triyono, Raharjo K, dan Rina A. (2015)."Pengaruh Kebijakan Dividen, Struktur Kepemilikan, Kebijakan Hutang, Profitabilitas, dan Ukuran Perusahaan Terhadap Nilai Perusahaan Pada Perusahaan Manufaktur di Bursa Efek Indonesia (BEI)". Jurnal Akuntansi Universitas Pandanaran Semarang Vol.1 No.1.

Try Hastuti dan Lena F. (2017). "Pengaruh Struktur Modal dan Ukuran Perusahaan Terhadap Kinerja Keuangan Pada Perusahaan Tekstil dan Garmen Yang Terdaftar di Bursa Efek Indonesia Periode 2010-2014".Jurnal Online Mahasiswa Administrasi Bisnis FISIP Universitas Riau.

Weygandt, Jerry J., Kimmel, Paul D., and Kieso, Donald E. (2011). "Financial Accounting IFRS Edition". United States of America: John Wiley \& Sons.

Wenny Rizky, 2016.Pengaruh Debt to Ratio, Total Turnover, dan Profit terhadap Earning Ratio.Universitas, Yogyakarta.

Yunita, Indah. (2011). “Analisis Pengaruh Profitabilitas, Kebijakan Utang, Kebijakan Dividen, Size, dan Mekanisme Good Corporate Governance Terhadap Nilai Perusahaan (Studi Kasus Pada Perusahaan Manufaktur yang Terdaftar Di Bursa Efek Indonesia Periode 2005- 2010)”.Tesis. Semarang: UniversitasDiponegoro. 